\title{
Porque os anjos são músicos
}

João Lupi (UFSC)

Resumo: A iconografia religiosa muitas vezes representa os anjos tocando instrumentos musicais. Porém a angelologia bíblica e a patrística referem-se aos anjos como seres místicos, que contemplam a Trindade, muitas vezes como mensageiros, por vezes como cantores, mas não explica porque são músicos, nem fala de instrumentos musicais. Percorrendo os tratados mais conhecidos - Orígenes, Pseudo Dionísio, Tomás de Aquino, Raimundo Lúlio - vemos que seus autores investigam a existência e a natureza dos anjos, suas funções como guardas e conselheiros dos indivíduos e das nações, ou como auxiliares no governo do universo (responsáveis pela harmonia das esferas?), mas não como músicos. Recorremos então à história da música e da pintura e à religião popular e encontramos uma relação entre o mundo angélico e o humano muito mais complexa e interessante do que se esperava.

Palavras-chave: anjos, música, liturgia, cosmologia

\section{WHY ANGELS ARE MUSICIANS}

Abstract: Religious iconography often represents angels playing musical instruments. Biblical and Patristic Angelology refers to Angels as mystical beings, who contemplate Holy Trinity; sometimes as messengers, or singers, but there is no explanation about Angels being musicians, neither about musical instruments. The best known treatises - those of Origen, Denys the Areopagite, Thomas Aquinas, Raymond Lull - ask about the existence and nature of the Angels, their functions as guards and counsellors of individuals and nations, or as auxiliaries of the government of the universe, perhaps as committed to the harmony of the spheres, but not as musicians. We searched on History of Music, and Painting, and on popular Religiosity, and we found that relationship between Human and Angelical worlds is much more complex and interesting than expected.

Keywords: Angels, Music, Liturgy, Cosmology

\footnotetext{
1 Artigo originalmente publicado nos Anais do XIII Congresso da Sociedade Brasileira de Filosofia Medieval. Metafísica, Arte e Religião na Idade Média. Vitória: DLL/UFES, 2013.
} 


\section{A questão e as hipóteses}

As representações dos anjos mostram geralmente seres humanos do sexo masculino, imberbes, jovens ou crianças, muitas vezes com asas, por vezes cantando, outras tocando instrumentos musicais. A masculinidade é resultado da influência do patriarcalismo judaico-cristão, atenuada, porém, pela ausência de barba; a masculinidade angélica nunca foi entendida literalmente porque quase sempre se pôs em dúvida e discutiu "o sexo dos anjos" como uma questão supérflua, já que os espíritos não têm corpo nem sexo. A juventude ou meninice representa a vida sustentada e eterna, e as asas a sua espiritualidade - porque, pela mobilidade total, não estão presos à terra. Mas porque esses espíritos, que têm uma vida feliz e sem fim, são músicos? O canto vocal e coral seria representação ou alegoria do canto espiritual, que os anjos entoam na presença divina: eles são seres místicos, que contemplam Deus sem intermediários, e a felicidade dessa visão às vezes é figurada pelo canto - note-se, porém, que os anjos da Bíblia não são cantores; por exemplo: no nascimento de Cristo (LC 2,13) não se diz que os anjos cantam, mas que entoam louvores e dizem "glória" (etc.). Resta-nos saber o significado dos instrumentos que aparecem na Escritura, como as harpas e liras do Rei David e as trombetas do Juízo Final; mas os tratados de angelologia quase não falam de música, e as histórias da música quase não falam dos anjos. Seria mais uma questão supérflua a propósito dos anjos se não se pudesse colocá-la como um sintoma de mudanças na estética e na cosmologia cristãs, visíveis na iconografia. As mudanças nas concepções estéticas, que alteram a teologia da música, podem-se encontrar através da história da música. Do ponto de vista da relação dos anjos com o cosmo a hipótese seria a seguinte: uma vez que os cristãos medievais deixaram de lado (não completamente) a ideia clássica de que os astros são seres espirituais e racionais e portanto se movem por si mesmos, a cosmologia começaria a ver no governo do cosmo pelos anjos, sob as ordens divinas, uma forma de manutenção da "harmonia" das esferas. Mas esta concepção por si só não explicaria os instrumentos angelicais e suas orquestras. Guiados, porém, por estes objetivos de pesquisa, fomos à procura da teoria 
musical cristã medieval: o que encontramos pode ser ponto de partida para outras investigações, mas não responde plenamente à pergunta inicial.

\section{Os anjos nas Sagradas Escrituras}

A angelologia tem amplo e sólido fundamento nas Escrituras, onde os bons espíritos são citados como mensageiros de Deus, conselheiros e protetores, e colaboradores de Deus no governo do mundo. Os mensageiros (malak) têm aparência humana (sem asas) e por vezes não fica claro se são mensageiros ou se é o próprio Deus que se manifesta em forma corporal. Os serafim e os querubim entraram na doutrina em épocas mais recentes do judaísmo, e não são mensageiros, mas místicos e contemplativos.

No período helenístico estas doutrinas foram mais desenvolvidas, e o Novo Testamento amplia as funções: os anjos são representantes do mundo celeste, intermediários, agentes do culto espiritual, anunciadores de boas novas; eles vêm das esferas celestes, e no final do mundo participarão do Julgamento.

No cristianismo eles são introduzidos pelo judaísmo intertestamentário, onde por sua vez foram recebidos através das religiões vizinhas: o zoroastrianismo (anjos bons e maus, lutas entre anjos), os serafim e querubim dos palestinos, e do gnosticismo. Muitos escritos judaicos, tanto os pseudoepígrafos (sobretudo o Livro de Enoque) como os escritos rabínicos, falam dos anjos e os descrevem; apenas uma discreta parte desses anjos entrou no Novo Testamento, mas uma grande quantidade de legiões angélicas foi conservada nos escritos cabalísticos (autênticos ou fantasiados) e são esses que hoje ressurgem na literatura de autoajuda e nos pseudo místicos. Porém nem as Escrituras recebidas pelas Igrejas, nem os escritos apócrifos e cabalísticos de vários tipos nos falam em anjos músicos - quando muito alguns cantam, mas não tocam instrumentos.

Do ponto de vista do plano salvífico de Deus os anjos não são parte intrínseca, nem na doutrina de Moisés/Yahwé nem no plano redentor de Jesus Cristo. Os anjos entram na Bíblia não por uma questão própria dos desígnios divinos, mas porque as pessoas já acreditavam neles e não os deixaram de lado. 
Eles não ocupam uma posição necessária e indispensável: teoricamente o mundo pode ser entendido sem os espíritos "mais-perfeitos-do-que-os-homens" ou "substâncias inteligentes separadas"; eles entraram nas Escrituras como componentes de um mundo espiritual complexo, originado em parte da reflexão sobre o modo de vida humano, para serem modelos de culto, e próximos a Deus. Como objeto de crença ocupam uma posição, essa de certo modo muito desejável, preenchendo a grande distância entre os seres humanos terrestres e a infinita transcendência divina.

\section{A doutrina cristã acerca dos anjos}

A Teologia especulativa sobre os anjos desde o início da Patrística se ocupou em descrever e explicar as diversas ordens de espíritos (três tríades), sua natureza ou ontologia, e sua vida perfeita na contemplação mística da Trindade. Nos primeiros séculos do cristianismo os teólogos dedicaram-se a estes temas, e posteriormente analisaram o culto aos anjos; mas as autoridades limitaram esse culto, não fosse o caso de levar os fiéis à idolatria: os cristãos deviam limitar-se a orações aos anjos, e por vezes o culto chegou a ser reprovado - por isso as imagens de anjos nos primeiros séculos são poucas.

O primeiro e mais importante tratado de angelologia cristã é As Hierarquias celestes de Dionísio Areopagita (séculos V/VI) que só foi divulgado na Europa ocidental no século IX pela tradução de João Escoto Eriúgena (c. 810 - c. 880). Além de descrever as hierarquias dos anjos, segundo as divisões e funções explicadas por São Paulo, o Pseudo Dionísio estabelece diversas categorizações, como a que coloca os anjos como a mais inferior das classes espirituais acima dos homens, e portanto mais em contato com os terrestres; mas aceita que se diga "anjos" para se referir a todas as categorias ou Tríades, desde os serafins até aos arcanjos e anjos, referência ambígua que se tornou comum até hoje.

Muitos teólogos escreveram sobre os anjos, seguindo geralmente a doutrina de Dionísio, inclusive Tomás de Aquino, de quem falaremos adiante. Entre os medievais destacou-se o místico Raimundo Lúlio (ou Llull, 1232-1316) 
que tratou dos anjos em diversas obras, e sobre eles redigiu um pequeno tratado. Nele trata, conforme descreve no início, das provas da existência dos anjos; da sua essência e outras disposições; da fruição ou gozo que eles têm na contemplação de Deus; da locução, ou do modo como se comunicam entre si e com os homens; da glória, ou excelência do conhecimento e do louvor; e finalmente dos anjos decaídos, ou demônios. Lúlio apresenta assim a temática mais abrangente e usual acerca dos anjos, porém de um modo ao mesmo tempo místico e racional, fazendo dele um exemplo característico da angelologia medieval (Llull, 2000).

$\mathrm{O}$ culto aos anjos e sua teologia continuaram nas Igrejas Orientais, e deles temos um bom exemplo nas Tríadas de Gregório Palamas (1296-1359). Segue a tradição do Pseudo Dionísio, que cita frequentemente, mas só Ihe interessam as questões místicas ou de caráter ontológico: os anjos celebram a glória divina e estão muito próximos de Deus, Dele recebendo a luz e o conhecimento; em sua contemplação saem de si mesmos, e ao unir-se a Deus são divinizados; por isso Gregório Ihes chama seres supra-cósmicos, isto é, além e acima de toda a criação material (Palamas, B5,B18,D10,D35,E16,E30,F16). Este foi o sentido predominante da angelologia oriental, com interesse quase exclusivo na natureza mística dos anjos, dando menos atenção às suas funções no governo do mundo (Palamas, 1983).

\section{A música litúrgica na Bíblia}

No povo de Israel a música era acompanhante usual das festas que celebravam os ciclos da natureza, e por isso recebia conotações alegóricas e espirituais: nos instrumentos de sopro, por exemplo, a música é considerada uma voz, uma manifestação do Espírito Divino (sopro, ruah, significava tanto o ar expirado como o espírito ou alma), chegando-se até a considerá-la como voz de Deus. Aquele que toca os instrumentos é religioso, próximo de Deus, pois tem uma função sagrada. Já os instrumentos de corda, como cítara, lira e saltério, são acompanhantes da voz, e sua melodia é um reforço para o sentido da letra, porque não existia música sem letra. As trombetas representavam a força de Deus 
sobre a terra: tocaram para derrubar os muros de Jericó, como os anjos as tocarão no Juízo Final para anunciar o poder de Deus e a Sua presença - contudo esse toque de trombetas, tal como as trombetas das batalhas, dificilmente pode considerar-se música. Mas, como a música acompanha as festas cíclicas da natureza, também tem por vezes significados cósmicos: a lira de sete cordas representa a harmonia universal dos sete sons e das sete cores, e a lira em sua forma simboliza o cosmo; e como nas festas se dançava, e as danças eram geralmente de roda (tipo ciranda), a dança humana representa e festeja a dança do universo, o rodar perfeito dos astros. Nestas concepções não há um papel específico para anjos músicos, a não ser no Apocalipse ( 4 e 5), em que os anjos e os santos celebram uma liturgia celeste.

A partir da destruição do Templo de Jerusalém, no ano 70 d.C., não se tocaram mais instrumentos na liturgia judaica; sem templo, a música passou para os locais de reunião, as sinagogas, onde se tornou exclusivamente vocal (Monrabal, 2006, p. 17-87).

\section{Música litúrgica nos primeiros séculos do cristianismo}

O modelo de canto judaico era do tipo "responsório": entoação pelo leitor, e refrão cantado pela assembleia; ela estava a serviço da letra, e a melodia evitava modulações do tipo teatral (hoje diríamos: de ópera). As primeiras comunidades cristãs pautaram-se pela liturgia judaica, com as modificações necessárias ao novo messianismo e ao culto do Senhor. A música litúrgica era exclusivamente vocal, austera e sóbria: pela influência direta da liturgia judaica, pela necessidade de discrição perante as perseguições, e pela oposição dos bispos à música profana.

O uso de instrumentos era reprovado, e a autoridade dos grandes pensadores cristãos - Clemente de Alexandria (c. 150 - c. 216), João Crisóstomo (347 - 407), Agostinho (354 - 430) - é unânime nesse ponto, pois o uso dos instrumentos musicais lembrava atitudes pagãs e mesmo demoníacas. Como essa proibição conflitava com a Bíblia os teólogos elaboraram uma doutrina segundo a 
qual o uso de instrumentos musicais pelos hebreus e judeus foi permitido por Deus como próprio de um culto imperfeito (Basurko, 2005, p. 149-173), e assim devem ser consideradas as muitas imagens do Rei David com seus músicos tocando instrumentos, que veremos estarem presentes na iconografia cristã. Entre os usos pagãos reprovados estavam as campainhas, que eram usadas para afugentar maus espíritos nas crianças, e por isso os cristãos não deviam usá-las; além disso, e falando de modo geral, se entendia que os instrumentos introduzem sons distintos, a heterofonia, adversa à homofonia (o som a uma só voz), que era preferível. Mas o povo cristão muitas vezes desobedeceu às recomendações dos bispos e dos teólogos.

Quando os Santos Padres citam instrumentos musicais o fazem como sendo alegorias da música espiritual, que deve ser característica dos cristãos (Basurko ib). O canto coral era considerado expressão do amor fraterno, de paz e harmonia, e o uníssono é a unidade na multiplicidade: uma só voz. O canto monódico é sinfonia (som conjunto) e por isso harmonia divina. O canto é sinal de amor, louvor e contemplação, mas só os puros devem cantar: o pecador impuro, se cantar, estará em incoerência com o seu estado, pois o canto principal é o interior, o da alma. O canto vocal, exterior, é sinal e manifestação do canto espiritual, que é um sentimento de alegria (Basurko, 2005, p. 38-107 passim). Esta espiritualização do canto faz com que por vezes os Santos Padres se refiram ao canto dos anjos: onde está o salmo aí está Deus e os seus anjos; “os anjos cantam hinos enquanto Jesus sobe aos céus", diz Atanásio; e ainda: os anjos cantam a uníssono (Basurko, 2005, p. 66, 75, 107).

Diversas referências nos fazem constatar que as práticas artísticas do cristianismo primitivo continuaram a receber influência da religião popular judaica (intertestamentária): uma das coleções de cantos (letra) mais usadas no século II era as Odes de Salomão, um conjunto de 42 hinos judaicos, onde transparece uma espiritualidade contemplativa, e ocasionalmente se fala em cantos e cítaras; as citações sobre o canto celestial dos anjos provêm de textos apócrifos, secundários, ou literários, como a Ascensão de Isaías (Basurko, 2005, p. 107 notas 35 e 36$)$. 
Esta era a situação do canto litúrgico cristão entre o século II e o IV; no final do século IV, possivelmente devido à maior liberdade de expressão, mas também por influência das Igrejas orientais e particularmente de Efrém Sírio, introduzem-se nas assembleias cristãs cantos mais animados, como os de caráter processional (Basurko, 2005, p. 37); mas os instrumentos continuavam proibidos pelos bispos - proibição que não conseguia atingir sempre sua finalidade, pois por algumas referências secundárias se sabe que cantores mais animados entravam nas igrejas.

No que se refere à dança e ao teatro não parece que tenha havido abrandamento das proibições, pois não só essas artes eram veículos do paganismo, mas eram também incentivos à lascívia. Por isso o papa Zacarias (741752) proibiu a dança nas igrejas; esse gênero de proibição já tinha existido, o que tornou a dança um divertimento profano, não sagrado, ou mesmo inconveniente para um cristão: a decretal de 774 alerta contra os "movimentos indecentes da carola" (dança de roda, Bourcier, 2001, p. 47). Apenas na Hispânia a dança religiosa, mormente com crianças, era permitida. Nestas condições seria difícil qualquer representação dos anjos que lembrasse a música dos teatros e da dança: quando muito poderiam cantar em coral, e nunca usar instrumentos, próprios de divertimentos profanos.

\section{Música, dança e teatro na Baixa Idade Média}

A partir da quase completa cristianização da Europa no início do século XI os perigos de paganismo, idolatria, e heresia ficaram mais distantes e pôde haver abrandamento em relação às artes. Sob influência do cristianismo as artes voltaram-se para temáticas religiosas, e algumas formas passaram a ser aceitas, como o teatro religioso que desenvolveu os mistérios e milagres. A dança foi permitida nas igrejas pelo Concílio de Avinhão (1209), contanto que não fosse na vigília dos santos - essas festas das vigílias dos dias santificados foram alvo de muitas reprimendas e advertências dos bispos, pois parece que o povo gostava de nessas noites cantar e dançar, nem sempre com o devido decoro. 
Mais para o final da Idade Média nova transformação surge nas artes, com a circulação de riqueza e a formação das burguesias nacionais; as cortes reais e feudais foram se tornando mais sofisticadas, e novas técnicas musicais se introduziram. Na segunda metade do século XV os mistérios separaram a música do texto: a melodia deixou de ser um reforço para a letra piedosa, e tornou-se um ornamento. O canto deixou de ser monódico e começou a utilizar instrumentos, e corais a várias vozes. No palco do teatro usava-se todo tipo de música: popular e erudita, polifônica e instrumental, e ainda o canto gregoriano (Chailley, 1950, p. $310)$.

Por volta de 1500 a imprensa começou a imprimir música; pouco depois, em Veneza já se imprimiam missais, motetes e canções; logo a França e a Alemanha seguiram o exemplo e multiplicaram a música impressa (Einstein, 1996. p. 55-56). Entretanto, por volta de 1500 a 1520, desenvolveu-se o canto acompanhado a instrumentos. Na época e até por volta da metade do século XVI a Holanda ainda dominava o panorama musical europeu, mas na segunda metade do século XV novas formas musicais, inclusive instrumentais, foram cultivadas na Itália e logo se expandiram para outras regiões (Einstein, 1996, p. 63 e 75) e o aperfeiçoamento das possibilidades da polifonia instrumental desenvolveu-se na Holanda e Alemanha.

Mesmo que os tratados de dança já existissem desde o século XIV algumas restrições religiosas à dança permaneceram no século XV, o que fez com que a dança se desenvolvesse apenas no âmbito profano, como divertimento popular e das cortes elegantes e sofisticadas, ou nos palácios da burguesia (Rey Marco, 1988, p. 216-217). A dança passou a ser um evento social organizado, e já era descrita com a intervenção de instrumentos: sacabuxa (tipo de trombone), charamela (antecessor do clarinete), e tambor (ib., p. 218). Porém: os instrumentos apareceram em cena, no teatro e na dança (não na igreja); eles são descritos e pintados, mas nas festas e nos palácios não são tocados por anjos (nem pintados). 


\section{Os instrumentos musicais medievais}

Conforme vimos o padrão estético-religioso cristão impedia o uso de instrumentos musicais nas igrejas e na música religiosa em geral, mais por motivos de ordem moral (para evitar o contágio da sensualidade pagã) do que teológicos.

Por isso as modificações que aconteceram gradualmente na música em geral, na dança e no teatro, a partir do século XI, se refletiram também no uso dos instrumentos. No final do século XIII o Codex Bamberg contém alguns motetes que só apresentam notação musical, sem texto, que podem ter sido compostos para instrumentos (McKinnon, 1990, p. 164); mesmo que esta suposição não seja certa o fato de os historiadores da música medieval aceitarem essa possibilidade significa que reconhecem que começava a haver um discreta introdução dos instrumentos musicais na música religiosa. A motivação é dupla: por um lado não representavam mais um incentivo à tentação pagã ou herética (os hereges os utilizaram muito), e por outro sua intervenção tornava-se necessária para acompanhar formas musicais cada vez mais complexas e trabalhadas. Orquestras de instrumentos de sopro atuavam fora das igrejas, mas por vezes entravam como complementos informais à liturgia, não no canto litúrgico oficial (McKinnon, 1990, p. 282).

A aceitação dos instrumentos musicais passou a ser mais nítida no século $\mathrm{XV}$ : desde o início do século os músicos começaram a obter mais lugar e respeito por parte da sociedade e no serviço litúrgico, mas sobretudo nas cortes mais luxuosas: a maior parte dos compositores da Borgonha e Flandres (principais regiões cultas da época) deste período estavam a serviço dos nobres. São raros os textos de composições para instrumentos porque o instrumentista profissional das cortes era um improvisador, que se fiava mais na memória e na criatividade do que nos textos, e cantando se acompanhava a si mesmo com harpa, alaúde ou guitarra (McKinnon, 1990, p. 278). Mas os textos existem: Conrad Paumann, de Nuremberg foi o primeiro a codificar a técnica do órgão e do alaúde na "tablatura", e a escrever os princípios do órgão como instrumento independente no "Fundamentum organisandi" (1452). A Alemanha foi pioneira no 
desenvolvimento da música instrumental; desde 1470 na Cartuxa de Buxheim, na Suábia, se copiou uma importante recolha de tablaturas para órgão, o Buxheimer Orgelbuch, e em várias cidades se criou um estilo autônomo de música de órgão.

O Norte e o Oeste europeus - Inglaterra, Borgonha, Flandres desenvolveram as técnicas polifônicas, compuseram obras em vários estilos, e as exportavam para o Sul (Itália, Ibéria) e para o Leste (Sacro Império). Em todas estas regiões se formou uma elite musical que passou além das tradições musicais regionais e deu início a uma música que se pode chamar européia. Mais sofisticada, essa música não estava ao alcance dos seres comuns, nem na composição, nem na execução, nem na apreciação (McKinnon, 1990, p. 297298). De fato, quando a música começa a tornar-se mais erudita, a avaliação comum é de que "existem notas que apenas os anjos e os seres do Paraíso conseguem perceber ou conhecer" (Secco, 1998, p. 131). Nos Países Baixos o florescimento da música deve-se em grande parte a uma base de incentivo público, presente no interesse pela música existente em confrarias e outros grupos cívicos que financiavam músicos e escolas de música.

\section{Iconografia musical}

Para reforçar e concretizar visualmente o que aprendemos com a história da música procuramos as representações pictóricas, concentrando-nos no seguintes tópicos: instrumentos musicais e anjos musicais - esse foi afinal o nosso ponto de partida.Com tal objetivo consultamos as reproduções de pinturas que ilustram as obras sobre história da música e as de história da pintura, geralmente intituladas história da arte.

A primeira imagem que encontramos é do século IV: o Bom Pastor tocando flauta pan, num mosaico de Aquileia (McKinnon, 1990, p. 77). A partir do século VII começamos a encontrar as imagens do rei David com seus músicos, uns tocando harpa, tamborim e alaúde (capa de marfim de um livro, McKinnon, 1990, p. 108), outros tocando cítara, sopros diversos, e percussão, e batendo palmas (Saltério de Vespasiano, Gowing, 1983, p. 405). Essas pequenas orquestras 
de David continuam nos séculos seguintes: na Bíblia de Carlos o Calvo, do século IX, em que os músicos tocam trompa e flauta longa, (McKinnon, 1990, p. 23); na Arte Musical de Aristóteles Beda, do século XIII, em que os músicos tocam viola, címbalo, órgão e percussão (Dufourcq, 1946, p. 113); e noutra imagem (ib., p. 118) o rei está com oito músicos tocando diversos instrumentos; e, já no século XV, o Rei David tocando com seus músicos de saltério, harpa e viola (ib., p. 131). Em todos esses conjuntos o rei toca cítara, ou harpa. Estes exemplos já nos asseguram de uma questão: o uso dos instrumentos musicais na liturgia era rejeitado pelos bispos e teólogos pela sua relação com cenas profanas, pagãs, ou sensuais, e não por si mesmos, pois de certa forma o Bom Pastor e o Rei David ao utilizá-los os santificaram.

As ilustrações de cenas em que os monges cantam em coral são mais comuns, por estarem mais conformes com as recomendações dos teólogos (por exemplo McKinnon, 1990, p. 100, manuscrito do século IX), e continuam a ser representados nos séculos seguintes (Bíblia francesa do século XIV, id, p. 235); e ainda no século XV os coros de monges e clérigos tonsurados continuam a aparecer, como um motivo permanente de música religiosa (ex.: McKinnon, 1990, p. 36) mas por vezes formam duas filas, como se cantassem em coros alternados ou a duas vozes (ib., p. 189 e 277).

Encontram-se algumas imagens de instrumentos e de músicos instrumentistas em contexto religioso, como uma do século XII, onde, na cerimônia de sagração de um cavaleiro, músicos tocam alaúde e viola de arco (Romance de Troia, Dufourcq, 1946, p. 107); mas o que começa a ser frequente no século XIII são os instrumentistas em ambiente profano, mesmo que incluídos em obras de caráter religioso como Livros de Horas, ou das Cantigas de Santa Maria; vemos assim um tocador de rabeca atrás do palco do teatro (Dufourcq, 1946, p. 134), um trio de cantores se acompanhando com a rabeca e guitarra (McKinnon, 1990, p. 185), tocadores de rabeca e alaúde (Dufourcq, 1946, p. 34), um dançarino se acompanhando em órgão portátil (ib., p. 52), um grupo (9) de meistersinger cantando e tocando - violas, tambor, sopro, harpa - diante do nobre e sua mulher (ib., p. 109), e um cortejo burlesco de mascarados com 
pandeiro (id., p. 115). Estas seis imagens, algumas do final do século XIII, provêm de vários reinos e regiões, e mostram uma boa variedade de instrumentos, mas estes sempre acompanham outra arte: teatro, poesia, canto ou dança.

O século XIV mostra maior profusão de imagens de instrumentos, e de músicos. Em quadros individuais, de um só executante, toca-se: flauta dupla, rabeca, guitarra menor, pandeiro, gaita de foles, flauta, pratos, harpa, órgão, alaúde, saltério, tamborim, saltério de 14 cordas, órgão de pedais, e trombetas (McKinnon, 1990, p. 183, 250; Dufourcq, 1946, p. 30, 46; Duby, 1997, p. 103. 121). Por vezes os músicos são representados em conjuntos, como pequenas bandas: em carnaval (McKinnon, 1990, p. 222), ou tocando para a rainha (ib., p. 242) num cortejo burlesco de charivari com máscaras que parecem macacos (Dufourcq, 1946, p. 97), ou em cena de corte elegante como "música de fundo" enquanto os senhores jogam (Power, 2001, p. 90). Também há cenas de dança, como duas rodas, de 4 mulheres cada uma, acompanhadas de pandeiro, viola e gaita de foles (Rey Marco, s/d, p. 215), ou dançarinos acompanhados por viola e flauta (ib., p. 216). Nestas seis imagens não há nenhum contexto religioso, todas são profanas: dança, cortejo, brincadeira, salão cortês.

O século XV mostra uma grande variedade de imagens de instrumentos e de músicos. Cenas de música na corte, com diversos tocadores de instrumentos, são mais frequentes; pode ser durante um banquete (McKinnon, 1990, p. 41), num cortejo de músicos (ib., p. 258), num casamento no salão do palácio (id., p. 28), ou na sala interior em que as damas tocam para um homem deitado (Dufourcq, 1946, p. 121). Os instrumentos destes diversos conjuntos são semelhantes aos que se viam nos séculos XIII e XIV mas mais sofisticados: trombone de vara, flautas mais longas, alaúde menor (mandora), espineta, viola da gamba, órgãos com maior número de tubos (McKinnon, 1990, p. 41, 258 , 279, 292; Black, 1993, p. 129; Dufourcq, 1946, p. 119). Grupos de músicas mulheres não são raros: em O Campeão das Damas nove mulheres instrumentistas tocam flauta, órgão portátil, trombeta, saltério, pífaro e alaúde (Dufourcq, 1946. p. 121). Também se vêem grupos mistos de mulheres e homens tocando instrumentos (ib., p. 159) e dançarinos de carole ao som de harpa e flauta (Power, 2001, p. 42). Mas a dança continua sob suspeita: numa tábua alemã 
sobre os Dez Mandamentos há um grupo de jovens dançando agarrados (homem com mulher) sob supervisão de um demônio (Rey Marco, 1988, p. 217).

O que pudemos constatar é que a partir do século XIV a música instrumental se afirmara e se tornara independente do contexto religioso, e que no século XV ela já estava perfeitamente constituída como música para uso profano. Cabe observar, porém, que esta pesquisa iconográfica, mesmo que fosse exaustiva, não seria conclusiva, pois não seria correto supor que a totalidade dos artistas representa fielmente a totalidade da vida social e cultural de uma época. 0 que a iconografia nos ofereceu foi um conjunto de indícios que reforçam o que nos disseram os historiadores da música.

O mesmo podemos afirmar a respeito das imagens de anjos músicos (instrumentistas), que se tornam frequentes no decorrer do século XV. Eles aparecem pela primeira vez num manuscrito inglês do século XIII, com asas e tocando viola, trombeta, alaúde, harpa (em "caixas" separadas de uma iluminura complexa, Dufourcq, 1946, p. 487) mas esse é um caso isolado, pois a maioria das imagens de anjos músicos é do século XV. Nestas alguns músicos são jovens com aparência angélica, mas sem asas: como o conjunto de instrumentistas e cantores pintado no painel do altar de Ghent (Gowing, 1983, p. 664; Black, 1993. p. 128 e 158-159). Os anjos tocam no nascimento do Menino Jesus (McKinnon, 1990, p. 41; Aston, 1996, p. 130) ou sentados aos pés da Virgem (Aston, 1996. p. 137). Os instrumentistas que portam asas e são sem dúvida anjos formam várias pequenas orquestras, em geral de meia dúzia de executantes cada: uns rodeando a Virgem (McKinnon, 1990, p. 306), ou formando um coro cantando em torno de Cristo (Gill, 1996, p. 65), tocando vários instrumentos (ib., p. 63), por vezes ensinando o Menino Jesus (Dufourcq, 1946, p. 120), rodeando a Virgem e o Menino num concerto angélico (ib., p. 126), ou presentes na consagração de um gentil-homem à Virgem (ib., p. 129), rodeando os santos doutores numa página de antifonário (ib., p. 105). Em todas elas os anjos são jovens imberbes, mas também há anjos meninos músicos, com asas, vestindo roupas curtas (ib., p. VI). Talvez a mais conhecida orquestra de anjos seja a que está nos quadros ou painéis de Hans Memling (1435-1494) em Bruges: eles tocam saltério, trombeta marinha, 
bombarda, alaúde, órgão portátil, trombeta, trombone, harpa e viola, formados em duas alas, e, como os demais, têm asas, e são jovens, imberbes, usando roupas longas (Dufourcq, 1946, p. 47). Fra Angélico também pintou uma orquestra de anjos na cena da coroação da Virgem (São João de Fiesole <1455, Dufourcq, 1946, p. 117) tocando alaúde, viola, três trombetas e pandeiro. Estas orquestras de anjos estão todas em contexto religioso: junto à Virgem e/ou ao Menino Jesus, ou a Cristo adulto, ou numa cena devota, e elas provêm da França (5). Flandres (4), Itália (incluindo os meninos e os sem asas), e Inglaterra (1); a proveniência do Norte da Europa pode explicar porque os anjos têm pele e cabelos claros (às vezes ruivos).

Assim, enquanto por um lado a música instrumental se torna mais autônoma e profana, sendo executada em palácios, jardins e cortejos de rua, e os próprios instrumentos e seus tocadores são valorizados por si mesmos e não só como "fundo musical" da letra, os anjos se "apropriam" dessa autonomia musical para compor suas próprias orquestras. A coexistência dessas duas situações é paradoxal: a autonomia e secularização da música instrumental faz com que ela "suba ao céu" e se torne angélica. A tendência da secularização da música é coerente com a independência do poder civil com relação ao eclesiástico, e mostra como esta divisão de poderes teve consequências na vida social e privada. Mas o que os pintores queriam significar ao representar orquestras angélicas neste contexto político-social? Queriam subtrair os anjos ao poder eclesiástico, que ainda não permitia o uso de instrumentos musicais? Embora pareça estranha, dita deste modo, a hipótese tem certo fundamento, pois foi nesta época que se generalizou o culto e devoção aos anjos da guarda, que passaram a ter uma função muito mais particular, de certo modo privada. Mas não resolve o paradoxo.

\section{Anjos, cosmologia e música}

Vejamos agora se há alguma relação entre os anjos e a harmonia das esferas. A multiplicidade dos céus era aceita pela tradição judaica, embora alguns 
rabinos a rejeitassem. Os primeiros autores cristãos não definiram uma opinião a respeito dos céus, mas foram adotando as doutrinas da época, sem grande preocupação de coerência, e alguns preferiram a cosmografia de apenas dois céus, ou dois níveis celestes. Porém os gnósticos eram adeptos da multiplicidade dos céus, colocando neles a hierarquia dos poderes espirituais, e também a ascensão gradual do conhecimento até ao Pleroma.

Os cristãos, embora combatendo os gnósticos, e se afastando das concepções judaicas incompatíveis com o cristianismo, aceitaram a ideia dos sete céus; assim o diz Irineu de Lião (c. 150 - c. 200) num escrito de 180, que imaginava os céus habitados pelos poderes divinos (Inglebert, 2001, p. 66-67). Mas as concepções populares judaicas, entre elas as já citadas dos Livros de Enoque, influíram no cristianismo; e no Livro dos Segredos de Enoque (Enoque II) e outros pseudoepígrafos judaicos dos séculos I e II d.C. se afirma que os astros e os fenômenos meteorológicos são controlados pelos anjos (ib., p. 35); pode-se pois supor que a ideia do ordenamento dos céus e dos astros pelos anjos tenha partido dessa fonte. Filon (20 a.C - 50 d.C.), o mestre judeu alexandrino, identificava os anjos com as estrelas, e Orígenes, que viveu no mesmo meio intelectual, afirmava que cada elemento do universo e cada astro tem um anjo que cuida dele, e que os astros são seres mais inteligentes do que os homens (Scott, 1994, p. 60, 70-71, 91-93, 128-141 etc.). Mas nem Enoque, nem Filon, nem Orígenes responsabilizam os anjos pelo ordenamento harmonioso dos movimentos celestes.

A influência dos pseudoepígrafos judaicos deve ter permanecido na religiosidade popular, pois o Pseudo Dionísio (entre 480/520) apresenta os poderes espirituais como colaboradores de Deus no governo do mundo, sem contudo estabelecer relação específica entre os anjos e a ordem do cosmo, pois prefere indicá-los como protetores ou guardiões das nações (Hierarquias Celestes 9.4). Segundo ele as ordens inferiores dos poderes espirituais participam do poder dos superiores "como parte da harmoniosa comunhão, universal e equitativa, em que todos se entrelaçam” (ib. 12.2 na tradução da BAC; ou: “comunhão única e universal, harmoniosa e sintética" na tradução de Roque Frangiotti, 2004). Os 
anjos são descritos pelo Pseudo Dionísio como cantores: "a teologia transmitiu aos habitantes da terra os hinos que cantam estes anjos da primeira ordem" (os serafins, ib. 7.4). O autor refere-se ainda a outra obra sua intitulada Hinos Divinos onde os cantos dos serafins seriam explicados, mas essa obra está perdida (ou não existiu).

Portanto para o Pseudo Dionísio os anjos (no sentido que ele mesmo expõe: todos os espíritos superiores) têm, entre outras, duas funções: contribuir para a harmonia universal e entoar hinos de louvor a Deus. Mas não empunham cítaras nem trombetas.

Tomás de Aquino foi talvez o teólogo que mais atenção dedicou aos anjos, não só na Suma de Teologia, mas em outras obras. Na Questão disputada sobre as criaturas espirituais aborda a questão "Se a substância espiritual se une a um corpo celeste" (art. $6^{\circ}$ ); mais prolixo do que o usual enumera catorze opiniões a favor da união de um espírito com um corpo celeste, e seis objeções. Discute essas doutrinas, e no final oferece vinte respostas, entre as quais a (1) de que as substâncias espirituais são os motores que movem os corpos celestes, e mais explicitamente (resposta à objeção segunda) diz que um corpo celeste é movido por um anjo, e (resposta à 3) é a comunidade dos anjos que move todos os corpos celestes. Doutrinas semelhantes confirma no Compêndio de Teologia ( $1^{\circ}$ Tratado, III, p. 75-78, 128, 171), e na Suma Teológica (I ${ }^{\mathrm{a}}$ q. 50-64); nesta trata sobretudo da vida mística dos anjos, da substância, da sua ação, do conhecimento e da linguagem, da função de guardiões, da hierarquia, do castigo dos anjos maus, ou seja, de modo geral de questões que poderíamos chamar ontológicas; as cosmológicas são abordadas como que de passagem, mas reafirma o domínio dos anjos sobre os corpos celestes (Ia 110, a.1, r. 2 e 3).

O ordenamento do cosmo associado à ideia de uma música das esferas, e um certo paralelismo entre anjos e ordem cósmica, ficou presente em crenças comuns até hoje em dia, por isso não é de admirar que mesmo na literatura essa ideia apareça: logo após dizer que existe uma música tão elevada que só os anjos a percebem, o personagem de Biopsirey acrescenta: "Ouvimos e apreciamos a musicalidade das Estrelas e a grande Sinfonia, realizada por todas as forças e energias emitidas e atraídas entre elas" (Secco, 1998, p. 131). 


\section{A música terrestre imita a celeste, ou é a angélica que imita a humana?}

As diversas religiões, e também o judeu-cristianismo, em suas concepções do universo incluíram vários tipos de seres espirituais, a que chamamos anjos, e Ihes atribuíram muitas funções, destacando-se, na angelologia cristã: a místicocontemplativa (na presença divina), a de mensageiros de Deus para os homens, a de conselheiros e protetores, tanto individuais como dos povos, e a de colaboradores no governo do universo. Tais funções têm uma doutrina básica fixa (presente por exemplo em Pseudo Dionísio e Tomás de Aquino) mas variando com as épocas e as regiões; no final da Idade Média a angelologia recebeu algumas conotações importantes: como protetores individuais os anjos da guarda foram muito valorizados e seu culto e doutrina se fortificaram, assumindo em parte as funções dos mensageiros; como colaboradores do governo do cosmo aparecem girando a máquina do mundo; e na função contemplativa, figurada pela música celeste, o canto a uníssono do Hossana passou a ser polifônico e acompanhado, quando não substituído, pela orquestra.

Os anjos começaram a usar instrumentos musicais porque os seres humanos passaram a utilizar cada vez mais instrumentos musicais; as orquestras do céu imitam as da terra, porque os artistas, como todas as outras pessoas, imaginam o que não veem na perspectiva do que conhecem. A correlação entre céu e terra, um sendo alegoria do outro, é normal, mas há nela um significado político: nas igrejas continua a cantar-se sem orquestra, ao passo que nas cortes feudais e reais há dinheiro, lazer e refinamento para contratar músicos e escutálos. Os anjos e o céu não reproduzem a cultura e o poder eclesiásticos, mas a cultura dos poderes civis, cada vez mais independentes da Igreja. Quando, no início do século XVI, Maquiavel (1469 - 1527) escreveu o Príncipe, libertando o governante da moral individual defendida pelos Espelhos dos Reis, já havia dois séculos de teorias políticas contra o poder eclesiástico, em defesa da autonomia do poder civil. 
Como em outros aspectos da teologia, em que se dá margem à imaginação coletiva, a angelologia não nos ensina só a respeito de quem são os anjos, mas também como eram as sociedades e mentalidades em cada época.

Porém outra interpretação é possível, mais religiosa e mística. Citamos Maria Victoria Triviño Monrabal (2006, p. 97): o pintor é aquele que percebe o invisível e o torna visível para entrarmos no mundo espiritual (da graça); para isso os artistas "colocaram perto da Senhora ou entre as nuvens do céu os anjos músicos. Quando o anjo tem nas mãos uma flauta, está convidando-nos a contemplar o êxtase da Mãe Santíssima. Se traz um tamborim, convida-nos à dança da alegria messiânica glorificando a Deus“. E continua dizendo que os anjos que tocam cítaras, alaúdes e harpas, estão nos mostrando a harmonia universal e a relação entre a música terrestre e a celeste; e quando tocam trombetas de prata querem que nos prostremos diante do poder divino. E a autora conclui: “Desperte cada um o anjo músico que leva dentro de si, até que chegue a hora de entoar o Cântico Novo com a cítara de Deus."

\section{Referências}

ASTON, Margaret (ed). The Panorama of the Renaissance. London: Thames and Hudson, 1996.

BASURKO, Xabier. O canto cristão na tradição primitiva. Trad. Celso Márcio Teixeira. São Paulo: Paulus, 2005.

BLACK, C.F. e outros. Cultural Atlas of the Renaissance. Nova Iorque: Prentice Hall, 1993.

BOURCIER, Paul. História da dança no Ocidente. Trad. Marina Appenzeller. São Paulo: Martins Fontes, 2001.

CHAILLEY, Jacques. Histoire musicale du Moyen Âge. Paris: PUF, 1950.

DUBY, Georges. A Idade Média. In: DUBY, Georges \& LACLOTTE, Michel (Orgs). História artística da Europa. Tomo I. Trad. Mário Dias Correia e Rosa Freire d'Aguiar. São Paulo, Paz e Terra, 1997, p. 103-121.

DUFOURCQ, Norbert. (dir) La Musique, des Origines a nos jours. Paris, Larousse, 1946.

EINSTEIN, Alfred. A Short History of Music. New York: Barnes \& Noble, 1996. GOWING, Sir Lawrence (ed). A History of Art. New York: Barnes \& Noble, 1983. 
INGLEBERT, Hervé. Interpretatio Christiana. Les mutations des savoirs (cosmographie, géographie, ethnographie, histoire) dans l' Antiquité Chrétienne, 30-630 après J.-C. Paris: Institut d'Études Augustiniennes, 2001.

LLULL, Ramon. O Livro dos Anjos. Trad. Eliane Ventorim e Ricardo da Costa. São Paulo: Instituto Brasileiro de Filosofia e Ciência Raimundo Lúlio, 2002.

McKINNON, James (ed). Man and Music. Antiquity and the Middle Ages. London: Macmillan, 1990.

MONRABAL, María Victoria Triviño. Música, dança e poesia na Bíblia. Trad. José Belisário da Silva. São Paulo: Paulus, 2006.

PALAMAS, Gregory. The Triads. Trad. Nicholas Goudle. New Jersey: Paulist Press, 1983.

POWER, Eileen. Medieval Women. London: The Folio Society, Ed. M.M. Postan, 2001.

PSEUDO DIONÍSIO AREOPAGITA. Obras completas. Trad. Teodoro H.Martin. Madrid: BAC, 1990.

PSEUDO DIONÍSIO O AREOPAGITA. Obra completa. Trad. Roque Frangiotti. São Paulo: Paulus, 2004.

REY MARCO Juan José. Danças na Idade Média e no Renascimento. In SALVAT. Enciclopédia Salvat de Os Grandes Temas da Música.Trad. Ana Mafalda Tello e Isabel F. Andrade. Rio de Janeiro, Salvat Editores do Brasil, 1988. Fasc. 54, 214221.

SCOTT, Alan. Origen and the Life of the Stars. Oxford: Clarendon, 1994.

SECCO, Victurino Antônio. A viagem a Biopsirey. Uma experiência além dos sentidos comuns. 2.ed. Florianópolis: Mente Aberta, 1998.

TOMÁS DE AQUINO, Santo. El mundo de los Espíritus. Cuestion disputada sobre las criaturas espirituales. Trad. Ana Mallea, comentário e notas de Celina Lértora Mendoza. Buenos Aires, Ed. Del Rey, 1995.

Compêndio de Teologia. Trad. Odilão Moura. Rio de Janeiro,

Presença: 1977.

Suma de Teología. Edición dirigida por los Regentes de Estúdios de las Províncias Dominicanas en España. Madrid, BAC, 1988, 5 volumes. Ia, Q.50-64 e passim. 